\title{
POTVORA, OBJEDA ZA NEMORAL: BEZAZLENA BIZARNOST, TRIVIJALNOST ILI TEŠKI GRIJEH U ISLAMU
}

\section{Sažetak}

Uzvišeni Allah, dž. š., šaljući Poslanike na zemlju, odgajao ih je, kao $i$ njihove sljedbenike kroz upečatlive dogadaje i iskušenja iza kojih je davao odgojne mjere i koristi koje se nikada neće zaboraviti. Nije poslao ni jednog od poslanika, a da ga nisu optužili da je ludak, ludi pjesnik, čarobnjak, prorok i sl., pa su tako i nevjernici, politeisti, idolopoklonici Kurejsa, na koncu svih poslaničkih misija, govorili za Muhammeda, a. s., čekajući priliku da mu na bilo koji način mogu naštetiti, napakostiti fizički ili moralno: njegovom ugledu $i$ moralu ili njegovoj porodici.

Samo jedan u nizu od tih napada jeste dogadaj ",ifka-a“ (hadisetul-ifk) u kojem su htjeli da Allahovog Poslanika, a. s., degradiraju moralno i psibički sa potvorom i objedom na njegovu ženu, majku muslimana, Aišu, r. a., kcerku Ebu-Bekra es-Siddika Istinoljubivog. Nakon mjesec dana strahovitih muka $i$ neprijatnosti, koje su se odrazile ne samo na Allahova Poslanika $i$ Aišu, r. a., njenu porodicu, nego i na citavo novoformirano muslimansko društvo i ashabe, Uzvišeni Allah će poslati Objavu kojom dokazuje nevinost Aiše, r. a., i kojom daje odgojne mjere i smjernice kojima će dalje kročiti muslimansko društvu nakon ovih strašnih dogadaja, ali će ukazati i na koristi svih ovih dogadanja kroz obznanjivanje $i$ otkrivanje nečega što muslimani nisu znali, a to je da medu njima ima prikrivenih licemjera koji su u njihovoj blizini i mecu njima. Dakle, ima onih koji nisu iskreni vjernici. Ovaj dogadaj ce raslojiti muslimansko drustvo na dvije kategorije: na iskrene vjernike koji su se držali istine i na one koji nisu, nego su se pretvarali da su vjernici i svoj prikriveni munafikluk i licemjerstvo koristili za napade na vjeru i vjernike.

${ }^{1}$ Islamski pedagoški fakultet u Bihaću 
Ključne riječi: potvora, objeda, hadisetul-ifk, licemjerstvo, munafici, licemjeri, Objava, Poslanik, a. s., Aiša, r. a., porodica Ebu-Bekra es-Siddika, Istinoljubiva, kćerka Istinoljubivog, (Es-Siddikatu bintus-Siddik).

\section{Uvod}

Otkad je Uzvišeni Allah poslao poslanike na zemlju, započela je serija napada na njih i to se ponavljalo kroz vijekove. Nije poslao ni jednog od poslanika, a da ga nisu optužili da je čarobnjak, luđak i sl. Tako su nevjernici pričali o svim poslanicima, a. s., a čak su nevjernici, politeisti, idolopoklonici Kurejša, na kraju krajeva, tako govorili i za Muhammeda, a. s. :

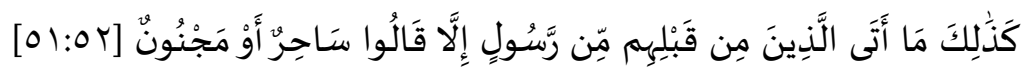

I tako je bilo, ni onima prije ovih nije došao nijedan poslanik, a da nisu rekli: 'Čarobnjak je!', ili: 'Lud je!'

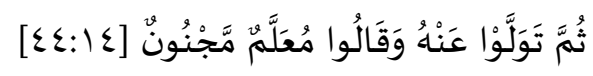

od koga oni glave okreću i govore: 'Poučeni - umno poremećeni!'

a on, uzdajući se u moć svoju, okrenu glavu i reče: "Čarobnjak je ili lud!" (51:39)

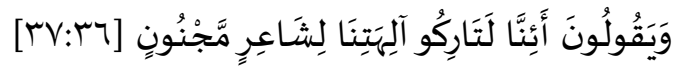

i govorili: 'Zar da napustimo božanstva naša zbog jednog ludog pjesnika?'

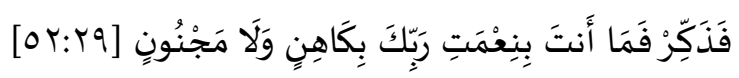

Zato ti opominji, jer ti, milošću Gospodara svoga, nisi ni prorok ni lud.

Zato ti opominji, jer ti, milošću Gospodara svoga, nisi ni prorok ni lud. (52: 29$)$

i govorili: "Zar da napustimo božanstva naša zbog jednog ludog pjesnika?" (37: 36)

od koga oni glave okreću i govore: "Poučeni - umno poremećeni!" (44: 14) 
Tu seriju napada na poslanike zapečatili su munafici i licemjeri Kurejša prema Muhammedu, a. s., čekajući priliku da mu na bilo koji način mogu naštetiti, napakostiti fizički ili moralno, njegovom ugledu i moralu.

Samo jedna u nizu od tih stvari jeste događaj u kojem su htjeli da Allahovog Poslanika, a. s., degradiraju moralno sa potvorom na njegovu ženu, majku muslimana, Aišu, r. a., koja je kćerka Ebu-Bekra es-Siddika - vidi samo koji nadimak je imao njen otac: Istinoljubivi - a i Aiša je također nosila taj nadimak Es-Siddika ili Istinoljubiva. Kako je ta potvora nekompatibilna i u kontradikciji sa značenjem njihovih nadimaka.

Ebu-Bekr je povodom tog događaja izjavio: Tako mi Allaha ni jedan napad na mene i moju porodicu nikada, ni u džahilijjetu ni poslije, nije bio veći $i$ teži od ovoga. U džahilijjetu smo obožavali idole i kipove pa i u takvoj situaciji nismo bili optuženi ni za kakav vid nemorala, niko nas nije optužio za takvo što, pa kako je moguće da nas optuže kada smo postali vjernici u jednog Boga, kada smo u islamu...

Bila je to strašna optužba koja je strahovito teško pala Aiši, njenoj porodici, Allahovom Poslaniku, a. s., koji je kada bi ga pitali: Koga najviše voliš na dunjaluku?, odgovorio javno: Aišu, ženu koju je neizmjerno volio, pazio, čuvao...

Objava kojom ga je počastio Uzvišeni tretirala je njegov bračni odnos sa njom. Objavom se saznalo da će je oženiti prije nego se to i desilo, i ona je bila ta koja je prenijela najviše hadisa od Allahovog Poslanika, a. s., a ujedno je i bila porijeklom najvišeg i najboljeg ranga, bila je kćerka EbuBekra es-Siddika ili Istinoljubivog. Ona je bila Istinoljubiva i kćerka Istinoljubivog Es-Siddikatu bintus-Siddik. Pa da vidimo kako je započela ta priča o potvori, kako se razvijala i rasla, i ko su bili njeni protagonisti, šta možemo izvući kao pouku iz čitavog ovog događaja. Također, treba da vidimo zašto licemjeri kroz historiju poslanstva i slanja poslanika, pa i u ovom slučaju, uvijek žele da okrnje ugled nekog od poslanika, a. s., zašto hoće da ih osramote pred ljudima i da učine bezvrijednim u očima ljudi? Zbog čega su izmišljali laži o njima i zašto su željeli da ljude okrenu od njih i protiv njih? To su šejtanska posla i stalna borba između dobra i zla. 


\section{Hadisetul-ifk (potvora) kroz vjerodostojna predanja}

\section{Odlazak na vojni pohod u pratnji žena i događaj koji će svratiti pozornost munafika}

O ovom slučaju Buharija i Ahmed su zabilježili duga, vjerodostojna predanja, hadise koje trebamo makar prepričati da bi shvatili pogubnost $\mathrm{i}$ štetnost potvore i objede koje se učine moralnoj, poštenoj osobi kao što je bila Aiša - Istinoljubiva, neporočna žena Allahovog Poslanika, a. s., i majka svih muslimana. Aiša pripovijeda o ovom događaju, što su zabilježili Buhari, Ahmed i drugi, nakon čega će Uzvišeni Allah objaviti deset ajeta sure En-Nur u kojima govori o nevinosti i neporočnosti majke muslimana. Ne možemo ni zamisliti kakav je to morao biti događaj i koje je sve konotacije imao po islam, muslimane, Poslanika, a. s., njegovu ženu, njenu porodicu i ashabe, kada je Uzvišeni poslao Objavu sa kojom ne samo da otkriva nevinost Aiše, r. a., nego otkriva i grupu licemjera unutar muslimanskog društva, dajući propise ponašanja, logiku kojom se trebaju rukovoditi vjernici u svom življenju i međusobnom ponašanju. Aiša kazuje:

Allahov Poslanik, s. a. v. s., kada bi odlazio na neko putovanje, bacao bi kocku među svojim ženama, pa čija bi kocka izašla, nju bi Allahov Poslanik, s. a. v. s., poveo sa sobom. Tako je bacio kocku medu nama za jedan vojni pohod na koji je krenuo, pa je kocka pala na mene i ja sam krenula sa Allahovim Poslanikom, s.a.v.s.To je bilo poslije propisivanja nošenja hidžaba. Ja sam nošena u mojoj nosiljci i u njoj sam boravila...

Putovala je na devi, u nosiljci, s velom koji je štitio žene od pogleda i ujedno su se mogle raskomotiti, pa im je bilo lakše podnositi put i veliku vrućinu. Dio karavane je bio za žene sa ljudima koji su se brinuli za taj dio karavane, vodili je, podizali nosiljke i radili sve drugo što je trebalo, bivajući na usluzi onih koje su u nosiljkama. Kad se pohod završio, u povratku, negdje pred Medinom su zastali, rasedlali deve, poskidali nosiljke i žene su sjele jedna sa drugom u društvu da se odmore.

Kada je Poslanik, a. s., dao naredbu za pokret, deve su osedlane, stavljene su nosiljke i odveli su ih ženama da se ukrcaju. Tada su neke žene, među kojima i Aiša, otišle malo u stranu da obave nuždu kako se ne bi poslije 
radi toga moralo stajati. Kada su se žene vratile, Aiša, r. a., je primijetila da joj je spala biserna ogrlica, i zaključila je da ju je izgubila na mjestu gdje je obavljala svoju potrebu. Ogrlica nije bila njena, nego od druge žene Umm Seleme i ona se vratila da je potraži. Našla ju je, ali se i zadržala. U međuvremenu je karavana otišla, a da niko nije primijetio kako ona nije u nosiljci.

Aiša pripovijeda: Žene su tada bile labke, ne teške i ne debele, jer su samo malo jele, pa tako da ljudima nije bila sporna labkoća nosiljke kada su je podigli i ponijeli, a i ja sam bila vrlo mlada. Oni su uputili devu i otišli, a ja sam našla svoju ogrlicu, nakon što je vojska već bila produžila. Stigla sam na njihovo mjesto, a tamo niti je ko dozivao, niti se ko odazivao...

Kada je vidjela da je ostala sama u pustinji, donijela je odluku da ne putuje za njima sama i pješke kroz pustinju, nego da čeka dok ne primijete kako je nema, jer će se neko sigurno vratiti po nju. Sjela je i čekala dok je san nije savladao. Zaspala je, a veo joj je bio spao s lica.

Prema jednoj verziji, jedan od ashaba, Safvan ez-Zekvani, imao je zadatak da izostane iza karavane, što je imalo praktičnu korist da ponovo pregleda ako je šta ostalo iza koga u logoru, tako da to može uzeti i ponijeti. Prema drugoj drugoj verziji priče, bio je čovjek teškog sna, nisu mogli da ga probude, pa kada se konačno probudi, krenuo bi za ostalima dok ih ne stigne. Aiša pripovijeda: Pa kada je vidio da se crnim, crnu siluetu na zemlji (što je dokaz da su sahabijke nosile crne ogrtače), prišao je da vidi sta se to tamo crni, vidio me je i prepoznao. (Jer ju je poznavao i prije nego što je počela nositi veo na licu). Rekao je: La havle ve la kuvvete illa billah, Mi smo Allahovi i Njemu se vraćamo.

Čuvši to skočila sam stavljajući veo na lice. On više nije prozborio ni jednu jedinu riječ. To je bio ashab koji je poštovao majku svih muslimana i nije više ni progovorio. Nije pitao ni šta je bilo s njom, ni zašto je izostala... Samo je prišao sa devom, okrenuo leđa Aiši, r. a., spustio devu na zemlju, stavio svoju nogu na nogu deve da bi Aiša bila sigurna da uzjaše. Čak nije rekao ni hajde, uzjaši, niti bilo šta drugo. Ona je uzjahala devu i on je, vodeći devu, bio okrenut leđima Aiši, r. a. Krenuli su put Medine. Nigdje nisu zastajali i stigli su karavanu koja se bila ponovo ulogorila 
kako bi vjernici klanjali akšam i jaciju, te se okrijepili. Oni su došli u logor, a Allahov Poslanik, a. s., uopće nije ni znao da je ona bila izostala. Za Aišu, r. a., to je bila velika neprijatnost. Otišla je do svoje nosiljke i nije znala da će to izazvati nečiju pozornost.

\section{Prilika za potvoru koju koristi Abdullah b. Ubejj b. Selul}

Međutim, njen dolazak u logor nije promakao munaficima, onima koji su samo čekali priliku da bilo šta iskoriste kako bi napali Poslanika, a. s. Vidio je to i Abdullah b. Ubejj b. Selul i njegovi istomišljenici. Oni su tražili bilo kakvu priliku za napad, slušali su svaku riječ, pažljivo posmatrali svaki događaj kako bi uočili bilo kakvu priliku i mogućnost za potvoru. Ukoliko toga nije bilo, onda bi nešto izmislili. Ako bi znali za kakvo dobro i pozitivnu stranu Poslanika, a. s., i vjernika, onda to bi prikrili i zanijekali. Radovali su se ako bi se desilo nešto loše, a ako se ne bi desilo, onda bi makar slagali da se desilo.

Vidjevši ovaj slučaj, Abdullah b. Ubejj b. Selul znao je da je to zlatna prilika za napad na Poslanika, a. s., ne bi li mu okrnjio ugled i ne bi li mu pristalice okrenule leđa, uz primjedbu: Što da slijedimo čovjeka čija porodica je takvog morala?

Abdullah je razglasio taj događaj u logoru u kojem je bio i Allahov Poslanik, a. s.,:

Allaha mi, nije se ona spasila od njega niti on od nje.

To nije bio ni prvi ni zadnji put da ovaj munafik napada Muhammeda, a. s., ovaj put preko morala njegove supruge, r. a. Prije toga je rekao o Poslaniku, a. s., i njegovim ashabima, muhadžirima: Situacija medu nama je kao situacija onoga śto je rekao: 'Napoj i nahrani svoga psa pojest će te, a izgladni ga i ima da te slijedi.' Zar se ovakvim vokabularom i ovom metaforom, ovim poređenjem govori o najboljem čovjeku, Poslaniku i njegovim ashabima muhadžirima koji su ostavili svoja imanja i došli u Medinu? Ništa oni nisu tražili od Ensarija, nego su im ovi ponudili svoja imanja, svoju porodičnu atmosferu, svoju zaštitu smatrajući da su im braća... Uzvišeni kaže, a iskreni vjernici Ensarije su to bili već prihvatili i 
praktično sproveli sa ugošćavanjem muhadžira koji su morali napustiti Mekku u svojim kućama i porodicama:

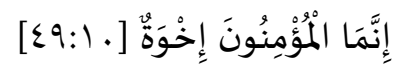

Vjernici su samo braća...

Munafici koji su se pretvarali da su vjernici su to nerado prihvatili, pretvarajući se da su vjernici, a čekali su bilo kakvu priliku da čine zlo muslimanima. I onda nije čudo što je njihov prvak Abdullah b. Selul zalajao: Allaha mi, ona se nije spasila od njega niti on od nje.

To je bio osvjedočeni munafik kojeg Allahov Poslanik, s. a. v. s., iz više razloga nije mogao pogubiti. Prenosi se da je nakon pohoda na BenulMustalik isti taj munafik rekao:

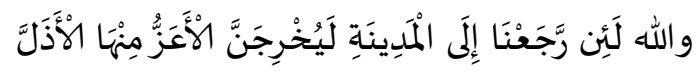

Allaha mi, ako se vratimo u Medinu, sigurno će jači istjerati iz nje slabijeg!

Ovim je mislio da će otjerati Allahovog Poslanika i muslimane. Kada je to čuo njegov sin Abdullah, inače jedan od poznatih ashaba, došao je Allahovom Poslaniku, a. s., i rekao:

$$
\text { "أنا رسول الله قد علمت المدينة أنه لا يوجد أحد أبر من أبيه مني فإن تريد قتله فأمرني }
$$

Allahov Poslaniče, sva Medina zna da nema nekoga ko je bolji od mene prema svome ocu. Ako želiš da se ubije, onda naredi meni jer ja ne bih mogao podnijeti ubicu svoga oca.

Kada se vojska vratila sa pohoda, među prvima je bio Abdullah koji je stao na ulaz u Medinu, isukao je sablju, pa kada je naišao njegov otac zaustavio ga je, uperio sablju u njegovo lice i nije mu dozvolio ulazak u Medinu rekavši mu:

$$
\text { والله لا تدخل حتى يأذن لك رسول الله }
$$

Allaha mi, nećeš uci dok ti to ne dozvoli Allahov Poslanik, a. s.

Ovaj munafik je bio poznat po tome što je rekao i ovo: 


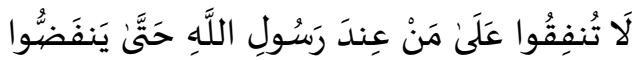

Ne udjeljujte ništa onima koji su uz Allahova Poslanika, da bi ga napustili!

Odnosno, nemojte davati zekjat i druge prihode, tako da se ljudi okrenu protiv njega, jer su beduini zbog toga dolazili, a ako nema materijalne koristi, onda beduini ne bi ni dolazili. Kada je to čuo Omer, zatražio je da ga ubije. Međutim, Poslanik, a. s., mu je rekao:

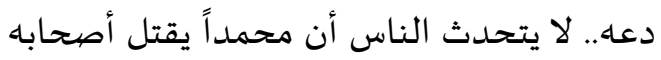

Ostavi ga... da ljudi ne bi pričali kako Muhammed ubija svoje ashabe.

\section{Postupak Allahova Poslanika, a. s., prema vođi munafika}

Kada je Abdullah b. Ubejj umro, njegov sin je zatražio od Allahovog Poslanika, a. s., košulju u koju će ga zamotati i pokopati. On mu je dao košulju, a zatim ga je zamolio i da mu klanja dženazu. Kada je Poslanik, s. a. v. s., krenuo da klanja, Omer ga uhvati za odjeću opominjući ga kako mu je to Allah zabranio, a on mu protumači 80 . ajet iz sure EtTevbe:

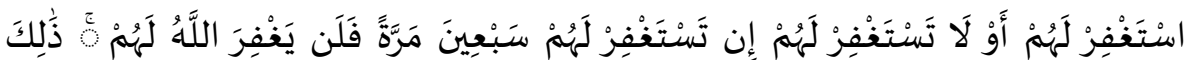

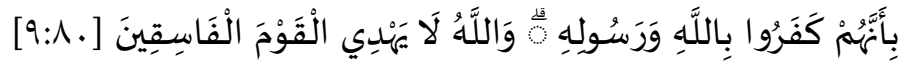

Molio ti oprosta za njih ili ne molio, molio čak i sedamdeset puta, Allah im neće oprostiti - zato što u Allaha i Njegova Poslanika ne vjeruju. A Allah neće ukazati na Pravi put nevjernicima.

Dato mi je na izbor, pokušat ću moliti i više od sedamdeset puta, rekao je Allahov Poslanik, a. s.

Koja ljubav i koji altruizam Allahovog Poslanika, a. s., prema ovome čovjeku. Pokušavao ga je spasiti, posljednji put upućivanjem dove Uzvišenom za tog čovjeka, pa makar na način da za njega moli i više od 70 puta, ne bi li se Uzvišeni smilovao. Iako je ovaj munafik govorio to što je govorio, iako se ponašao tako kako se ponašao, Poslanik, a. s., moli za njega ne bi li se Uzvišeni smilovao i oprostio mu. 
Ibn-Omer pripovijeda: I klanjao mu je Allahov Poslanik, a. s., dženazu, a onda je Uzvišsni objavio ajet u kojem se to eksplicitno zabranjuje Poslaniku, a. s. U 84. ajetu iste sure stoji:

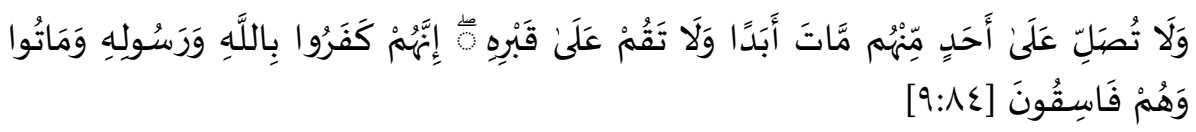

I nijednom od njih, kad umre, nemoj molitvu obaviti, niti sahrani njegovoj prisustvovati, jer oni u Allaha i Njegova Poslanika ne vjeruju $i$ kao nevjernici oni umiru.

Nakon njegove smrti pokret munafikluka je stagnirao, neki licemjeri su se povukli, a neki su još ostali, ali ih niko nije znao osim Huzejfe bin elJemana, obaviještenog o tajnama koje je znao samo Allahov Poslanik, a koji ga je obavijestio o njihovim imenima.

Dakle, ovi su izmislili tu potvoru i napali na čast i ugled Poslanikove, a. s. žene. A Aiša, r. a., neporočna žena, nevina, bogobojazna, majka svih muslimana, vjernika - ništa ne zna o potvori, ne zna o objedi ovog munafika i njegovih sljedbenika, ne zna da je to uopće izrečeno. Kad je to saznala, nije mogla da shvati da je mogla biti izrečena takva gnusna laž u muslimanskom društvu i da bude prihvaćena kao mogućnost. Pošto nije ništa znala o svemu tome, otišla je do svoje jahalice, svoje nosiljke i dalje krenula sa karavanom put Medine. Za nju je taj događaj bio završen.

\section{Licemjeri svakog vremena i prostora koriste ista sredstva}

Međutim, to nije bilo završeno za munafike, za Abdullaha b. Ubejja b. Selula koji je tu objedu i potvoru nastojao što više razglasiti. To je metoda koju koriste licemjeri u svakom vremenu i prostoru, od davnina pa do danas, i Abdullah je iskoristio sva sredstva koja je posjedovao da ovu laž plasira među svijet.

U današnje vrijeme postoji tzv. sedma sila koja je to preuzela na sebe (neki kažu i četvrta sila), a to su mediji koji prenose slične vijesti. Da je i to imao, ovaj munafik bi upotrijebio. Porijeklo pojma sedma sila veže se za vrijeme Francuske revolucije, kad je novinarstvo imalo veliki utjecaj. Pojedini novinari tada su imali veći utjecaj i od najutjecajnijih političara. 
Napoleon je nazvao novinarstvo petom silom u Evropi, a prve četiri bile su Francuska, Velika Britanija, Rusija i Austrija. Shvatio je važnost novinarstva i nastojao ga nadzirati.

Ujedinjenjem Italije 1861. i Njemačke 1871., broj sila u Europi povećao se za dvije, pa je peta sila spala na sedmo mjesto. No, neki izvori tvrde da su Velika Britanija, Francuska, Austrija, Pruska, Rusija i Turska bile tih šest sila ispred sedme. Čak i gubljenjem petog mjesta, snaga novinarstva još uvijek je bila neporeciva.

Postoje i druge igre brojki kada je riječ o novinarstvu. U društvima koja su imala tri staleža, novinarstvo je proglašavano četvrtim. U Americi je novinarstvo bilo proglašeno četvrtom vlašću - nakon zakonodavne, izvršne i sudske. Ove igre brojki, kada je riječ o novinarstvu, oslikavaju ulogu istog $\mathrm{u}$ javnost i politici.

U vrijeme ovoga događaja o kojem pripovijedamo koristilo se usmeno predanje i klasična metoda ogovaranja, a da je ovaj munafik imao ikakvo drugo sredstvo osim svog poganog jezika, upotrijebio bi ga. Napisao bi novinarski članak, dao izjavu za TV, otišao na Facebook, razglasio na sve četiri strane svijeta. Ne bi se ničega libio za ostvarenje svojih munafičkih ciljeva.

I do današnjeg dana postoje munafici i mrzitelji islama koje Kur’an opisa na slijedeći način:

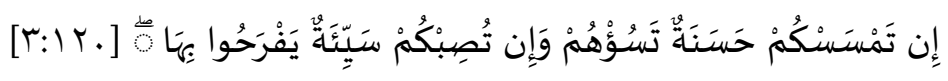

Ako kakvo dobro dočekate, to ih ozlojedi, a zadesi li vas kakva nevolja, obraduju joj se...

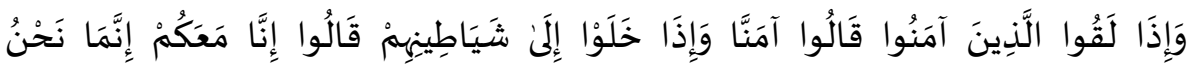

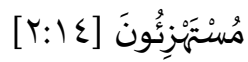

Kada susretnu one koji vjeruju, govore: 'Vjerujemo!' - a čim ostanu nasamo sa šejtanima svojim, govore: 'Mi smo s vama, mi se samo rugamo.'

Imaju isto to svojstvo prijetvornosti kroz historiju, kroz vijekove. Oni to i dan-danas upražnjavaju, kada se radi o islamskim vrijednostima; ako se radi o ljudima koji se bore za vjeru (misionari, borci na Božijem putu i 
sl.), pokušavaju da ih obezvrijede, da njihove namjere i nijjete predstave sumnjivim i sl. Tako je bilo i u vrijeme Allahovog Poslanika, a. s. Ako bi vjernik donio sadaku i dobrovoljni prilog Allahovom Poslaniku za potrebe države i muslimanskog društva i sirotinje, munafici bi rekli onome koji donese puno: Ovaj se samo pravi i pretvara, on je licemjer; a ako ne bi imali dajući malo, rekli bi: Allah i Njegov Poslanik to ne trebaju. A Uzvišeni je objavio:

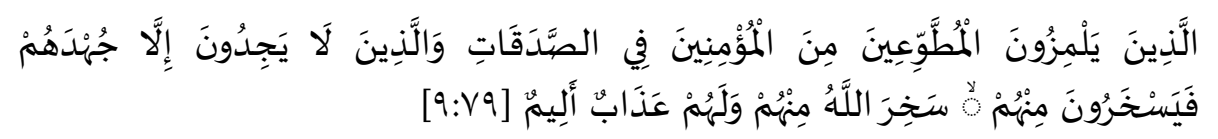

One koji vjernike ogovaraju zato što zekat daju, a rugaju se i onima koji ih s mukom daju - Allah će kazniti za izrugivanje njihovo, i njih čeka patnja nesnosna.

Njihov pravi problem je bio u tome što su oni bili neprijatelji Onoga koji poznaje ljudsku dušu, ljudsku unutrašnjost i skrivene namjere. On, Uzvišeni, otkriva tu njihovu unutrašnjost da bi vjernici to znali, iako se licemjeri skrivaju.

I u današnje vrijeme ista je situacija. Primjera radi, ako neko sakuplja dobrovoljne priloge za opću stvar, odmah je primjer za podozrenje i sumnju, obijedi se i potvori. Ako drži vazove i predavanja, i za njega ubace sumnju, a ako mu išta mogu naći - naprave od muhe slona. Ako napiše knjigu ili ako izađe u medije, nastoje da ga proglase nepodobnim, sumnjivim i sl. Ako ode svojim sredstvima i svojim imetkom da se negdje bori za islam, proglase ga teroristom. Upravo sve po onom ajetu: $A k o$ kakvo dobro dočekate, to ih ozlojedi, a zadesi li vas kakva nevolja, obraduju joj se...

Ovako su postupili munafici i u ovom slučaju, koristeći ovu zlatnu priliku da napakoste Allahovom Poslaniku, a. s., njegovoj porodici i njegovim najiskrenijim ashabima.

\section{Aiša saznaje za potvoru}

Muslimani su se vratili sa puta u Medinu. Aiša ne zna ništa šta se događa u kuloarima munafika koji šire neistinu u medinskom društvu, što 
direktno pogađa Allahovog Poslanika, a. s. Ona se vratila, odsjela u kući Allahovog Poslanika, a. s., iscrpljena od puta, bolesna - što je slučaj sa mnogima kojima našteti promjena mjesta boravka, putovanja i sl. Legla je u postelju još uvijek ne znajući šta se dešava.

Tada nije bilo televizora, nije bilo žute štampe i jednostavno nije znala šta se dešava, a niko joj to nije htio reći. Allahov Poslanik, a. s., slušao je glasine što ga je činilo jako nesretnim, iako je Uzvišeni kazao:

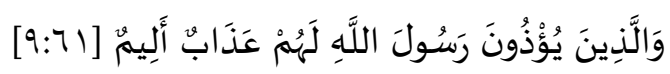

\section{(...) a one koji Allahova Poslanika vrijedaju čeka patnja nesnosna.}

Aiša je bila bolesna u krevetu, on je dolazio da je posjeti i ništa kod njega nije primijetila neobično, osim da nije postupao sa njom nježno kao što je postupao ranije kad se razboli. Naime, on bi je ranije gladio po glavi, nasmijavao, pokušavao oraspoložiti, međutim, sada je samo ulazio u sobu pitajući jedino: Kejfe tilkum? (Kako si?), i na tome se završavalo.

Aiša je nakon nekog vremena malo prizdravila i sa jednom od rodica, daljih tetki svoga oca, izašla iz kuće da se pripremi, okupa i sredi za svoga muža. Sa njom je bila Ummu Mistah. Spotakla se i onako u ljutnji spomenu sina nekom kletvom, a Aiša iznenađeno upita:

- Kako to govoriš o ashabu koji je bio učesnik Bedra?

- Ma znaš li ti šta on o tebi kaže?

- Šta kaže?

I tek tada je Aiša prvi put čula šta su munafici zakuhali, a drugi prenosili. Obaviještena je: Rekli su o tebi tako, tako i tako ...

Aiša se iznenadila, potpuno izgubila, problijedjela... Bila je još uvijek djevojče od petnaestak godina. Upitala je svoju rodicu koja i svog sina proklinje zbog toga, znajući da je Aiša nevina:

- Rekli su to o meni?

- Da! Rekli su!

- Čaršija to priča, javno? 
$-D a !$

- Došlo je to do ušiju Allahova Poslanika, a. s.?

- Da!

Tek tada se Aiša istinski razboljela. Tražila je od Allahovog Poslanika, a. s., da je pusti roditeljima da se tamo okrijepi, a htjela je da vidi o čemu se to radi, o čemu ljudi pričaju, da joj roditelji to objasne. Odlazi roditeljima i pita majku:

- Jesi li čula, šta se priča?

Majka ju je pokušavala smiriti:

- Dešava se da iz zlobe, ljubomore, zavisti i sl., o ženi koja ima inoče $i$ poznatog muža pričaju ružne stvari da je diskredituju isl.

- Ti si čula ranije?

- Da!

- Pa što me nisi obavijestila? Pričaju li po gradu i je li to došlo do Poslanika, a. s.?

- Jeste!

Pita i oca, Ebu-Bekra koji odgovara isto. To je strašno teško palo i EbuBekru. Aiša je plakala danonoćno. Pomislili su da će joj srce puknuti od silnog plača, da će se razboljeti zbog toga. Nisu vidjeli izlaza. U tom periodu Džibril je uobičajeno donosio Objavu Poslaniku, a. s., ali ništa što bi se odnosilo na Aišu.

Allahov Poslanik, a. s., hodao je Medinom, a zli jezici su prepričavali ono što se odnosilo na njemu najvoljeniju osobu na dunjaluku. Kako je to teško padalo Allahovom Poslaniku, a. s., što je, naravno, tako veselilo i radovalo munafike.

\section{Postupak Allahovog Poslanika, a. s.}

Poslanik, a. s., kako to kaže Kur'an, ne govori po hiru svome, a Objava nije ništa spominjala o potvori. To ga je tištilo do te mjere da je jedan dan pozvao Aliju i Usamu b. Zejda da ih pita o rastavi sa Aišom. Alija je 
bio njegov zet i muž njegove kćeri Fatime, odrastao i odgojen u kući Poslanika, a. s. Poznato je bilo da je bio mudar i pametan, da je znao dati pametan savjet. Usama je također rastao i bio odgajan u kući Poslanika, a. s. On je upitao:

- Jesi li ikada išta primijetio kod Aiše što bi moglo ukazivati na ovakav grijeh? Bio si sa nama čitav svoj život, ima li ikakva indicija da upućuje na to ili bilo šta drugo???

- Ništa! O njoj znam samo hajr i dobro! Ima samo svojstva istinoljubive, ima namaz, dovu, zikr, dobrovoljni namaz, sve, sve samo hajr i dobro...

Sličan je bio i Alijin odgovor.

- O njoj znam samo dobro! Ali ti imaš i druge žene, šta te to pogada od nje. Uostalom, pitaj njezinu sluškinju Beriru, sigurno će ti reći istinu!

Allahov Poslanik, a. s., uz sve državne probleme, borbe, brige za državu, za muslimane, sirotinju i sl, ni u svojoj kući nije bio miran od munafika. Našli su način da mu pokvare i kućni mir. Pitao i Beriru, sluškinju:

- Ti si sa njom dan i noć, znaš kada izlazi, kad ulazi, kad jede, kad spava. Sve znaš. Ima li išta da si primijetila kod nje?

- Nista! Ima samo jedna primjedba, ona je mlada i kad potkuham kruh i ostavim da nadode, ona zna zaspati, onda dođu ovce ili jarad i pojedu ga. Eto jedine primjedbe na nju koju ja znam.

Dakle, svi oni koji su imali ikakvu vezu sa Aišom znaju o njoj samo hajr i dobro. Svi daju pozitivnu preporuku o njoj, hvale je i ne vide joj nikakve mahane. Nasuprot toga, munafici je sve više olajavaju i Allahov Poslanik, a. s., se naposljetku penje na minber u džamiji, što je značilo da hoće da progovori o vrlo važnoj stvari. Naime, na minber se nije penjao osim ako je trebalo obavijestiti o ratnom pohodu, pomoći i spasiti sirotinju, odbraniti muslimane od napada neprijatelja, ili ako se radilo o nekoj drugoj jako važnoj i bitnoj stvari. Svi su se odazvali znajući da je nešto važno. Poslanik, a. s., se oglasio:

Ljudi, ko će me više osloboditi i spasiti od čovjeka koji me ne ostavlja čak ni sa mojom porodicom?, naravno, misleći na Abdullaha b. Ubejja b. Selula. 
Javlja se i Sa'd b. Mua'z, koji je primio islam u svojoj 26. godini, a preselio u 33. godini. Za njega se u biografiji prenosi da se zbog njegove smrti zatresao i A'ršur-Rahman.

Ja ću te spasiti, Allahov Poslaniče, ako je čovjek iz moga plemena Evs, skratit ću ga za glavu, a ako je iz plemena Hazredž, postupit ću kako mi narediš.

Bio je vođa plemena Evs, a sa plemenom Hazredž imali su stalne svađe i nesporazume još iz predislamskog doba. U njihovu kompetenciju se nije htio miješati, osim uz direktnu naredbu Allahovog Poslanika, a. s. Dakle, onaj ko te uznemirava, ko priča potvore o tvojoj ženi i sl., zaslužio je smrt. I složio se Allahov Poslanik, a. s. Međutim, tada se diže Sa'd b. U'bade, jedan od najautoritativnijih plemenitih ashaba iz plemena Hazredž i kao njihov prvak staje u odbranu pripadnika svoga plemena, brata po plemenskoj liniji, ne po islamu, pa reče Sa'd b. Mu'azu: Nećeš ti, Boga mi, ubijati moje ljude i moje saplemenike. Ko si ti da ubiješs nekoga iz moga plemena?!

U odbranu je stao i drugi ashab te optužio Sa'da da je i on munafik, da brani munafike. Ashabi se međusobno posvađaše i razgalamiše toliko da je lahko moglo doći do većeg obračuna. Allahov Poslanik, a. s., je cijelu situaciju s krajnjim naporom i strpljivošću uspio smiriti i utišati.

Sišao je sa minbera i okrenuo prema kući Aiše. Bilo je prošlo mjesec dana od događaja potvore, Objava je uobičajeno dolazila, ali se ništa nije odnosilo na taj događaj.

\section{Vrhunac potvore i njenog djelovanja na Aišu, r. a.}

Dok je trajala Aišina bolest, to je bio prvi put da se Poslanik, a. s., zaputio njenoj kući. Aiša kazuje da je plakala cijelu noć, pa i noć poslije. Nije jela ni pila i pomislili su da će se ozbiljno razboljeti od plača, bola i tuge.

Istinoljubiva, džennetska čistunica, majka muslimana, optužena da je iznevjerila svoju čast i čast Poslanika, a. s. - to je jednostavno bilo nepodnošljivo. Ubijala se neprestanim plačem. Poslanik, a. s., ulazi u njenu kuću, kod njenih roditelja, a ona sklupčana na postelji, potpuno iznemogla, jednostavno ne može da se pokrene. Allahov Poslanik, a. s., ju 
gleda, svoju ženu, svoju ljubav, koju je neizmjerno volio, s kojom se družio, šalio, igrao, dizao na ramena da može preko njega vidjeti Abesince kako slave Bajram svojom igrom i pjesmom. Kada bi se zbog nečega naljutila pokušavao ju je oraspoložiti... Kada je bivao upitan ko mu je najdraži od ljudi, odgovarao je: Aiša; puno puta je hvalio njenog roditelja, Ebu-Bekra. Međutim, kako se desio ovaj slučaj, nije ju dotakao punih mjesec dana, a kamoli pokazao neki drugi vid nježnosti i ljubavi. Nije sa njom posjedio čitav mjesec dana. A sada ga ona, onako sklupčana, iscrpljena do krajnjih granica, u neizmjernom grču i bolu, nepomična na postelji, gleda suznih, gotovo ugaslih očiju.

Aiša pripovijeda: Bila sam u prisustvu roditelja i jedne žene Ensarijke kada je Poslanik, a. s., došao, sjeo, okrenuo se ka meni i nekako procijedio:

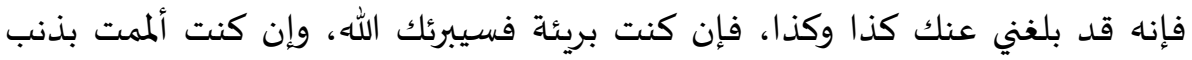

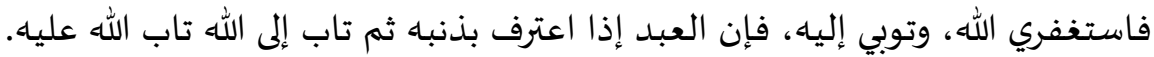

'Došlo mi je do ušiju da se o tebi priča tako i tako..., ako si učinila grijeh, pokaj se Gospodaru, Uzvišenom Allahu, jer kad neki rob Božiji učini grijeh, pa se iskreno pokaje, Allah mu i oprosti, a ako si nevina, nevino optužena, Allah će te opravdati i zaštiti.

Uspio je reći samo ovo i ništa više. Kada je ovo izrekao, stale su mi suze od strahote spoznaje da i Allahov Poslanik, a. s., daje dvije moguínosti za ovaj dogadaj: mogućnost da se grijeh desio ili nije desio - možda jedno, a možda drugo. Je li moguce da $i$ ti (sine Brute, što bi rekla rimska poslovica), Allahov Poslaniče, vjeruješ da se tako nešto uopće moglo dogoditi? Zar postoji i ta mogućnost, uopće?!

Aiša pripovijeda: Suze su se skamenile, ni jedne više... Pogledala sam u oca (a koga će drugog...), pa rekoh: Babuka, odgovori Allahovom Poslaniku! Jer, ako iko postoji ko mi vjeruje pa to je moj babo.

Ebu-Bekr je mogao samo zaplakati i reći: $A$ šta da odgovorim i sa kakvim argumentom da se obratim Allahovom Poslaniku, a. s.?

Okrenula se majci: Majčice, odgovori Allahvom Poslaniku. Odgovor je bio isti kao i kod oca: Ne znam šta bih rekla... 
Aiša je utihnula. Bila je još uvijek djevojčica od petnaestak godina, a onda je rekla:

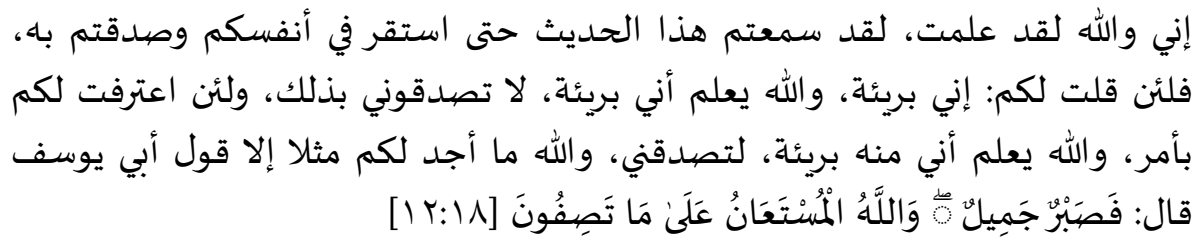

Allaha mi, vi ste čuli potvoru, gdje je pričaju i prenose, ona vam je ušla u vaša srca i vi ste povjerovali. A da vam kažem, da sam nevina - a Allah zna da sam nevina - vi mi ne biste povjerovali, a da kažem učinila sam - a Allah zna da nisam - vi biste povjerovali. Allaha mi, ja više ne znam kako bih ovo izmedu nas drukčije kvalifikovala nego kao primjer Jusufovog oca, (htjela je da kaže Ja'kuba, ali joj nije naumpalo ime pa je rekla Ebu-Jusuf), koji je rekao:

'... i ja se neću jadati, od Allaha ja tražim pomoć protiv ovoga što vi iznosite.'

Zatim sam se pokrila po glavi i nastavila plakati.

Dakle, nekad se dođe u situaciju koju više čitav dunjaluk i ljudski rod ne može ništa da riješi. Može samo Jedan i Jedini - Bog. I to se i desilo.

\section{Objava daje konačan stav po ovom događaju}

Aiša dalje kazuje: Poslanik, a. s., nije se pomakao sa mjesta, niti je ko izašao iz kuće, kada ga zadesi stanje koje je imao prilikom dolaska i spuštanja Objave. I ovaj put mu je to bilo izuzetno teško i naporno.

Naime, kada bi se spuštala Objava na Allahovog Poslanika, njega bi obuzelo stanje u kojem se preznoji, ma kakvo hladno vrijeme bilo, dok se ne završi objavljivanje. Jednom prilikom kada se to dešavalo, jedan ashab je bio u blizini Allahovog Poslanika, a. s., čije koljeno je bilo naslonjeno na njegovo, pa je imao osjećaj da će ga zdrobiti od težine Objave koja je silazila na Allahova Poslanika, a. s. Uzvišeni kaže:

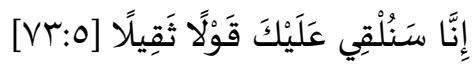

Mi ćemo ti, doista, teške riječi slati. 
Dakle, obuzelo ga je stanje kada prima Objavu, znoj ga oblio. Kada je došao u prirodno stanje, bio je radostan. Uskliknuo je: Aiša, raduj se! Uzvišeni te je opravdao!

Majka se obratila Aiši: Kćeri, skoči i zahvali Allahovom Poslaniku, a. s. Otac isto tako!

$$
\begin{aligned}
& \text { لا والله لا أقوم إليه ولا أحمد إلا الله عز وجل، فأنزل الله عز وجل:)إن الذين جاءوا }
\end{aligned}
$$

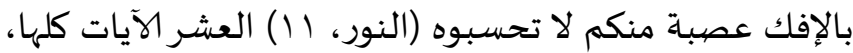

Neću, tako mi Allaha, zahvalit ću samo Uzvišenom, mome Gospodaru koji me opravdao! Nisam ni pomislila da će Uzvišeni Allah objaviti ajete o meni u Kur'anu, smatrala sam da nisam dostojna toga da to Uzvišeni objavi u Kur'anu. Jedino sam priželjkivala da Poslanik, a .s., usnije istinite snove i da na takav način sazna istinu od Gospodara.

Međutim, Uzvišeni je poslao Objavu u vidu deset ajeta iz sure Nur.

\section{Neki aspekti ajeta koji se odnose na potvoru i odgojne mjere za takvu situaciju}

U suri En-Nur, u kojoj se nalaze ajeti o ovom događaju, Uzvišeni je prvo govorio o preljubi i njenoj zabrani, zatim o onima koji potvaraju muslimane i muslimanke, zatim je rekao:

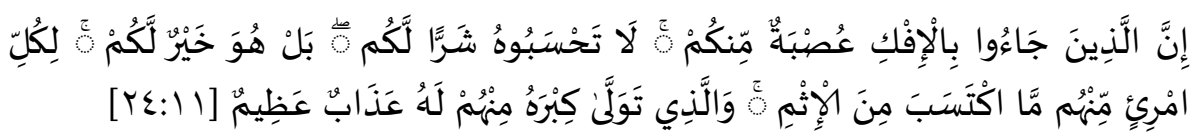

Mecu vama je bilo onih koji su iznosili potvoru. Vi ne smatrajte to nekim zlom po vas; ne, to je dobro po vas. Svaki od njih bice kažnjen prema grijehu koji je zaslužio, a onoga od njih koji je to najviše činio čeka patnja velika.

Tefsir: Riječ potvora, ifk, je najveća moguća laž, a (u'sbetun), trojica/do devet, međutim, nemojte smatrati da vam je to zlo, nego dobro. Ovim događajem Uzvišeni otkriva munafike koji se pretvaraju da su vjernici pa ih Uzvišeni iskušava i otkriva, tako da ih vjernici mogu prepoznati prilikom tih događaja po njihovom odnosu, postupku i njihovim aktivnostima. Tako je bilo i u ovom slučaju, međutim, svaki od njih bit će 
kažnjen prema grijehu koji je zaslužio, a onoga od njih koji je to najvišse činio čeka patnja velika.

U ovom slučaju to je bio Abdullah b. Ubej b. Selul. Zatim je Uzvišeni poučio vjernike kako se mora i treba ponašati u takvim situacijama:

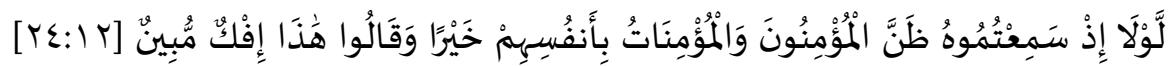

Zašto, čim ste to čuli, nisu vjernici i vjernice jedni o drugima dobro pomislili i rekli: 'Ovo je očita potvora!'

Ovo je odgojna mjera za vjernike od strane Allaha Uzvišenog, kroz kazivanje o Aiši, r. a., kada su se upustili u taj ružni govor. Uzvišeni kaže: Zašto niste, čim ste to culi, vjernici i vjernice jedni o drugima dobro pomislili, tj. prosudili prema sebi, pa ako njima samima takvo nešto nije bilo dolično, onda majka pravovjernih treba da bude čista. Ovo je objavljeno o Ebu-Ejjubu, Ensariji, i njegovoj ženi, Allah bio njima zadovoljan. Ebu-Ejjubu je rekla njegova žena: Zar nisi čuo šta ljudi pričaju o Aiši, r. a.? Odgovorio je: Da, i to je laž. Da li bi ti to uradila, o UmmiEjjub? Rekla je: Ne, Allaha mi, ne bih to uradila. Ebu-Ejjub reče: Pa, Aiša je, Allaha mi, bolja od tebe. Zato se riječi Uzvišenoga:

Zašto, čim ste to čuli, nisu vjernici i vjernice jedni o drugima dobro pomislili i rekli: 'Ovo je očita potvora', odnose na ono što su rekli EbuEjjub i njegova žena.

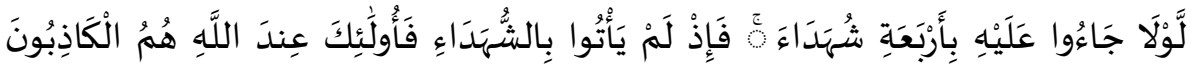
[r: $r: Y]$

Zašto nisu četvericu svjedoka doveli? A pošto svjedoke nisu doveli, oni su onda kod Allaha lažljivci.

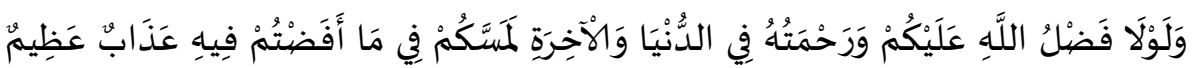

A da nije Allahove dobrote prema vama i milosti Njegove i na ovome i na onome svijetu, već bi vas stigla teška kazna zbog onoga u što ste se upustili

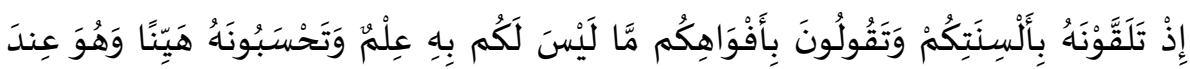

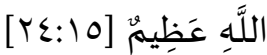


kad ste to jezicima svojim prepričavati stali i kad ste na sva usta govorili ono o čemu niste nista znali, a vi ste to sitnicom smatrali, ali je ono Allabu krupno.

Potvora, objeda je užasan grijeh i nedjelo, teški haram, prezrenost $\mathrm{i}$ pokuđenost koja ne bi smjela da se nađe kod čovjeka, pogotovo ne kod vjernika. Nažalost, u današnjem vremenu ta pojava je tako raširena kao da se radi o nekom beznačajnom, malehnom, trivijalnom djelu, sitnici djelu koje je dozvoljeno, iako se u islamu tretira kao vid teškog harama. Potvaranjem, objedom i upotrebom laži, namještanja, korištenja polulaži i poluistina stvara se pogrešna slika i predstava o nekom ili nečem, pogrešne predrasude čije je negativne posljedice nemoguće izbjeći.

$U$ ajetu se kaže: vi ste to sitnicom smatrali, ali je ono Allahu krupno. Kod Buharija i u Muslimu nalazi se hadis /299/: Covjek rekne riječ ne znajući koliku je Allahovu srdžbu izazvala i koja ga odnese u Vatru većeg raspona od mectuprostora Neba i Zemlje. U jednom predanju dodaje se: ne pridavajući joj važnost.

Hafiz Ebul-Kasim et-Taberani prenosi od Huzejfe da je Vjerovjesnik, s. a. v. s., rekao /303/: Potvora poštene žene ruši dobra djela učinjena za sto godina.

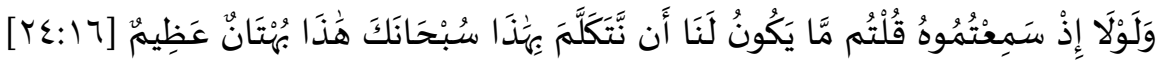
Zašto niste, čim ste to čuli, rekli: 'Ne dolikuje nam da o tome govorimo, hvaljen neka si Ti! To je velika potvora!'

Ovo je druga odgojna mjera koja naređuje lijepo mišljenje prilikom spomena riječi kojih nisu dostojni vjernici, pa je najpreče da se o njima promisli dobro, a ako i osjeti nešto u duši, ne smije se to iznositi zbog njegovih, s. a. v. s., riječi /300/: Allah Uzvišeni oprašta mome ummetu ono što im duše govore, ako to ne kažu ili ne učine. Naveli su ga Buharija $\mathrm{i}$ Muslim. Allah Uzvišeni kaže:

Zašto niste, čim ste to čuli, rekli: 'Ne dolikuje nam da o tome govorimo.'

Nije nam potrebno da izustimo ovakav govor, niti da ga ikome spominjemo. 
Uzvišen neka si Ti! To je velika potvora!, tj. slavljen je Allah i nedozvoljeno je da se kaže ovakvo nešto protiv žene Njegova Poslanika i prijatelja.

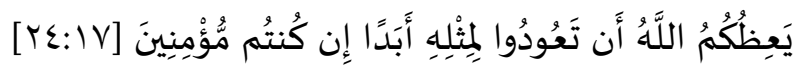

Allah vam nareduje da više nikad tako nešto ne ponovite, ako ste vjernici.

Dakle, za vjernike se ne smatraju oni koji to nastave raditi.

Zatim Uzvišeni kaže: Allah vam naređuje da više nikad tako nešto ne ponovite, tj. Allah vam prijeti i upozorava vas da vam se ne desi nešto slično u budućnosti. Odnosno, ako takvo šta dalje budete govorili, onda niste vjernici, što eksplicitno upućuje na nevinost Aiše, r. a., inače bi to bilo dozvoljeno. Zato je rekao: ako ste vjernici, tj. ako vjerujete u Allaha i Njegov zakon i ako poštujete i uvažavate Njegova Poslanika, s.a.v.s.Međutim, kad je riječ o nevjerniku, na njega se odnosi neki drugi sud.

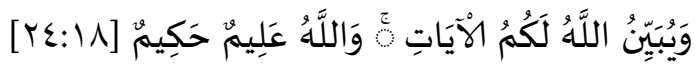

...i Allah vam propise objašnjava; a Allah sve zna $i$ mudar je.

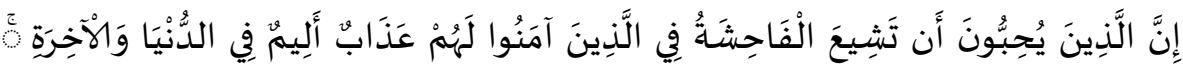

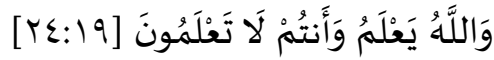

One koji vole da se o vjernicima šire bestidne glasine čeka teška kazna $i$ na ovome i na onome svijetu; Allah sve zna, a vi ne znate.

Ovo je treća odgojna mjera za onoga ko čuje neki ružan govor - da ga ne širi i ne obznanjuje. Uzvišeni kaže:

One koji vole da se o vjernicima šire bestidne glasine čeka teška kazna, tj. one koji su odabrali iznošenje na vidjelo ružnog govora o njima, čeka teška kazna i na ovom svijetu, tj. putem šerijatske sankcije (hadda), a na vječnom svijetu kazna. Allah sve zna, a vi ne znate, tj. prepustite Njemu takve stvari, ispravno ćete postupiti. Imam Ahmed prenosi od Sevbana da je Vjerovjesnik, s. a. v.s ., rekao /301/: Nemojte uznemiravati Allahove robove. Nemojte ih grditi i ružiti. Nemojte tražiti njihove mahane i sramote, 
jer ko bude tražio sramotu svoga brata muslimana i Allah će njemu tražiti, tako da će ga osramotiti u njegovoj vlastitoj kući.

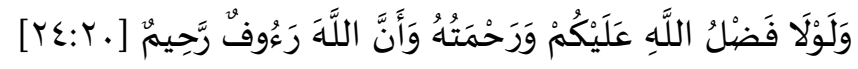

A da nije Allahove dobrote prema vama i milosti Njegove i da Allah nije blag i milostiv...

\section{Zaključci}

1. Poslanik, a. s., kako se razumije iz ovog događaja, ipak je samo čovjek i poslanik kojem se objavljuje. Nije imao mogućnost da u Objavu uvrsti ono što se njemu svida ili da odbacuje ono što mu se ne svida. U suri ElHakka (44-49) kaže se:

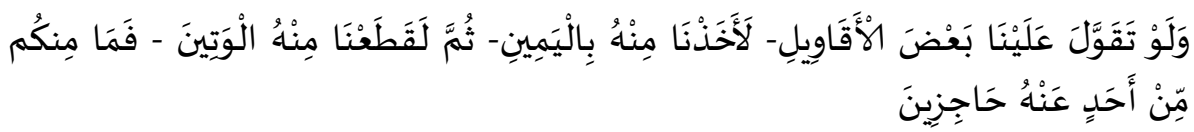

A da je on o Nama kojekakve riječi iznosio, Mi bismo ga za desnu ruku uhvatili, a onda mu žilu kucavicu presjekli, i niko ga između vas ne bi mogao od toga odbraniti.

Dakle, mjesec dana i više Poslanik, a. s., doživljava nesnosnu duševnu patnju i bol, kao i njegova žena, majka muslimana, Aiša, r. a., njena porodica, te svi vjernici $\mathrm{i}$ ashabi, pa ipak čitavo to vrijeme nema Objave koja će razriješit spomenutu teškoću. A da je Muhammed, a. s., izmišljao Kur'an, onda se na to ne bi čekalo;

2. Ovaj događaj je bio povod da se propiše sankcija za potvoru u vidu bičevanja sa osamdeset štapova, da se onome ko to uradi ne prima njegovo svjedočenje sve dok se ne pokaje;

3. Uzvišeni Allah je imao najispravniju, najefektniju i najprimjereniju metodologiju odgajanja poslanika i vjernika koja se sprovodila kroz praksu i nezaboravne događaje. Zbog toga je Allahov Poslanik, a. s., neposredno odgajajući ashabe metodologijom koju mu je dao Uzvišeni, postigao rezultate i odgojio neponovljivu generaciju koja je spomenuta i u Kur'anu. Ta generacija je odgajana na različite načine i različitom metodologijom, pa čak i čudima, mudžizama, žrtvovanjem, vođenjem 
bitaka, odricanjima, strpljivošću itd. Bili su ispitivani iskušenjima, nekada takvima da se krv ledila od njihove težine, a događaji koji su to pratili bili su škola za generacije vjernika do Sudnjega dana. Jedan takav događaj je svakako primjer potvore i objede žene Poslanika, a. s., Aiše, r. a., koja je nepravedno potvorena da je učinila preljubu, zinaluk koji je bio povod i predmet Objave i javljanja Uzvišenog sa ajetima sure En-Nur, koji će se učiti iz Kur'ana do Sudnjega Dana. U tim ajetima Uzvišeni i Svemogući Bog je presudio o njenoj nevinosti, čistoći, ispravnosti, i neporočnosti; Uzvišeni je dao rješenje u predmetu i stvari koja je mogla nepovratno da podijeli, zbuni i zavadi prve muslimane, da im nanese nemjerljivu štetu kao i štetu razvoju i širenju islama.

\section{Literatura}

1. Kur'an i prijevodi Kur'ana

2. El-Kur'anu-l-kerim, Mushafu-l-Medinetin-Nebevijjeh (Kur'an Časni, medinska verzija Mushafa), (Mudžemme’u-l-melik Fehd, 1405. god. po H.),

3. Dr. Al-Hilali Muhammed Taqi-ud-Din i dr. Muhammed Muhsin Khan, Interpretation of the Meanings of THE NOBLE QUR'AN in the English Language (Interpretacija značenja Svetog Kur'ana na engleskom jeziku) (Maktabe Dar-us-Salam, Riyadh, 1993.),

4. Karabeg H. Ali Riza, Prevod Kur'ana, (SKD, Bavaria Verlag \& Handel GmbH, München, 1990.),

5. Korkut Besim, Kur'an s prevodom, (Štamparija kralja Fehda, S. Arabija, Medina, 1412. god. po H.),

6. Mlivo Mustafa, Kur'an sa arapskog na bosanski, (Bugojno, 1995.),

7. Pandža-Čaušević, Kur'an Časni, (Stvarnost, Zagreb,1978.);

\section{Knjige i brošure}

1. 'Alauddin es-Semerkandi, Tuhfetu-l-fukahai (Raritet za islamske pravnike), (Idaretu ihjait-turasi-l-islami, bez godine izdanja),

2. Ed-Dusuki, Hašijetud-Dusuki 'aleš - Šerhi-l-kebir, (Dusukijeva glosa na Šerhul-kebir) i na margini: Muhammed 'Alejšs, Eš-Šerh (Komentar), (Daru-l-fikr, bez godine izdanja),

3. Ebu-l-Hasen en-Nedevi, Es-Siretun-nebevijje (Biografija Vjerovjesnika, a. s.), (Daruš-šuruk, Džidda, S. Arabija, 1979), 
4. Ebu-Zekerijja Muhjuddin b. Šeref en-Nevevi, El-Medžmu'u šerhu-l-muhezzeb (Zbirka stilizovanog komentara), (Daru-l-fikr),

5. El-Hummam (En-Nizam) i grupa učenjaka iz Indije El-fetava el-hindijje fi mezhebi-l-imamil-e'azami Ebi Hanifeten-Nu'man (Indijske decizije u pravnoj školi imamu-l-e'azama Ebu Hanife en-Nu'mana, poznate i kao El-fetava el'alemkirijje) (Daru ihjait-turasi-l-'Arebi, Bejrut, četvrto izdanje, bez godine izdanja), sa dodatkom još dvije knjige u istom kompletu-knjizi:

6. Fetava Kadija han (Decizije Kadija Hana), i

7. El-fetava el-bezazijje (Decizije Bezazija),

8. Ibn-Džerir et-Taberi, Džami’u-l-bejan fi te'vili aji-l-Kur'an (Sveobuhvatni komentar u hermeneutici kur'anskih ajeta), (Daru-l-Fikr, 1984.),

9. Ibn-Hadžer el-'Askalani, Fethul-Bari bišerh Sahihu-l-Buhari (Pomoć Stvoritelja kod komentara Buharijeve Vjerodostojne zbirke hadisa), (Darur-rejjan litturas, Kairo, 1987.),

10. Ibn-Kesir, Tefsir Ibn-Kesir, skraćeno izdanje, Izabrao najispravnije verzije Muhammed Nesib er-Rifa'i, (Visoki saudijski komitet, Sarajevo, 2000.),

11. Ibn-Tejmije, Medžmu’u fetava (Zbirka decizija), (Izdanje kralja Fehda b. 'Abdulaziza, 1398.),

12. Ibrahim b. Muhammed el-Halebi, Multeka-l-ebhur (Sastajalište mora), (Muessesetur-risale, 1989),

13. Muhammed b. 'Ali eš-Ševkani, Fethu-l-kadir (Pomoć Moćnog), (Daru-l-fikr, 1973.),

14. Muhammed b. Ahmed el-Kurtubi, El-Džamiu' liahkami-l-Kur'an (Zbornik propisa Kur'ana), (Daru ihjait-turasi-l-'Arebi, Bejrut, Libanon, 1985.),

15. Muhammed Džemaluddin el-Kasimi, Mehasinut-te'vil (Ljepote komentara Kur'ana), (Daru-l-fikr, 1978.),

16. Muhammed b. Džerir et-Taberi, Džami’u-l-bejan 'an te'vili aji-l-Kur'an (Jasni zbornik komentara kur'anskih ajeta), (Daru-l-fikr, 1988.),

17. Muhammed b. Džerir et-Taberi, Džami’u-l-bejan 'an te'vili aji-l-Kur'an (Jasni zbornik komentara kur'anskih ajeta), (Darul-fikr, 1405/1984.),

18. Muhammed Emin, poznat kao Emir Padišah, Tejsirut-tahrir, šerh Emir Badišah, ala Kitabit-tahriri fi usuli-l-fikhi-l-džami’i bejne-stilahajji-l-hanefijjeti veš-šafi ’’jjeti (Jednostavna, lahka redakcija, komentar Emira Padišaha na knjigu Spis o metodologiji islamske jurisprudencije $s$ komparativnom metodom hanefijske i šafijske škole), (Daru-l-baz, bez godine izdanja),

19. Muhammed Emin, poznat kao Ibnu 'Abidin, Hašijetu reddi-l-muhtar, poznata kao Hašijjetu Ibni 'Abidin (Glosa Ibni 'Abidina), (Daru-l-fikr, 1979.), 
20. Muhammed eš-Širbin el-Hatib, Mugni-l-muhtadži ila ma'rifeti me'ani elfazi-lminhadž, šerh (Bogatstvo potrebnom u poznavanju značenja „Minhadža“komentar), (Daru ihjait-turasi-l-'Arebi, Bejrut, Libanon, 1958.),

21. Muhammed Husejn et-Tabatabai, El-Mizanu fi tefsiri-l-Kur'an (Metoda, vaga u hermeneutici Kur'ana), (Muessesetu-l-e'lemi li-l-matbu'at, Bejrut, Libanon, 1997.),

22. Muhammed b. Idris eš-Šafi' i, El-Umm (Majka), kompendijum Muzenija, (Daru-l-ma'rife, Bejrut, Libanon),

23. Muhammed Nesib er-Rifa'i, Tejsiru-l-Alijji-l-kadir libtisari tefsir Ibn Kesir, (Olakšavanje Uzvišenog, Moćnog u sižeiranju komentara Ibn Kesira), (Bejrut, 1978.),

24. Muhammed b. Rušd el-Kurtubi, Bidajetu-l-mudžtehid ve nihajetu-l-muktesid, (Početak pravnog eksperta i kraj umjerenog), (Daru-l-kutubi-l-'ilmijje, Bejrut, Libanon, 1988.),

25. Safijjurrahman el-Mubarekfuri, Zapečaćeni džennetski napitak, (Porodična biblioteka, Visoki saudijski komitet, Sarajevo, 1998.),

26. Sejjid Sabik, Fikhus-sunne (Islamsko pravo u sunnetu), (Daru-l-fikr, Bejrut, 1977.),

27. Sejjid Kutub, Fi zilali-l-Kur'an (U hladovima Kur'ana), (Daruš-šuruk, 1993.),

28. Škapur Hasan (prevodilac), Buharijina zbirka hadisa, (I,II,III), (R\&R, Tuzla, 1994.)

29. Škapur Hasan i Hasan Makić (prevodioci), Buharijeva zbirka hadisa, (IV), (ElKalem, Sarajevo, 1991.),

30. Šihabuddin, Ebu-l-'Abbas, el-Karafi, El-Furuk (Razlike), ('Alemu-l-kutub),

31. Šemsuddin Muhammed 'Arefe ed-Dusuki, Hašijetud-Dusuki 'alešs-Šerhi-l-kebir (Glosa Dusukija na Veliki komentar), (Daru-l-fikr),

32. Dr. Vehbe ez-Zuhajli, El-Fikhu-l-islamijju ve edilletuh (Islamsko pravo i njegovi dokazi), (Daru-l-fikr, Damask, 1984.),

33. Zafer Ahmed el-'Usmani, I'laus-sunen (Uzdizanje sunneta), (Idaretu-1-Kur'ani ve-l-'ulumi-l-islamijje, Karači, Pakistan, 1415. god. po H.),

34. Zejnu-l-'Abidin b. Ibrahim b. Nudžejm, El-Ešbahu ven-nezairu ala mezhebi ebi Hanifeten-Nu'man (Sličnosti i uporednosti pravne škole Ebu-Hanife EnNu'mana), (Daru-l-kutubi-l-ilmijje, Bejrut, 199),

35. Zekijjuddin el-Munziri, Et-Tergibu vet-terhibu mine-l-hadisiššserif (Stimuliranje i zastrašivanje kroz hadis Allahovog Poslanika, a. s.), (Muessesetut-tarih vet-turasi-l-'arebi, 1968.). 
Muharem Stulanovic, PhD

\section{FALSE CHARGES, FALSE ACCUSATIONS OF IMMORALITY: HARMLESS BIZARRE ACT, TRIVIALITY OR A GRAVE SIN IN ISLAM}

\section{Abstract}

The Almighty Allah has raised His messengers as well as their followers through memorable events and temptations which provided corrective measures and the benefits that will never be forgotten. He did not send any of the messengers except that he was accused of being a lunatic or a mad poet, magician, prophet, etc. In this way the disbelievers, polytheists, idolaters of Quraysh, on the peak of all messengers' mission, have spoken about Muhammad, peace be upon him, waiting for an opportunity to harm him in any way, spike him physically or morally, both his reputation and morale or his family.

Just one in a series of such attacks is the event "ifka-a " (hadis al-ifk) in which they wanted to degrade Allah's Messenger morally and psychologically by slandering his wife, mother of believers, Aisha, the daughter of Abu Bakr As-Siddiq. After a month of terrible anguish and discomfort, which had an impact not only on both Allah's Messenger and Aisha, but also on her family and the whole newly formed Muslim society, Allah sent revelation proving the innocence of Aisha. The revealed verses provided educational measures and guidelines which continue to tread the Muslim society after these terrible events, but also pointed out the benefits of all these events through the disclosure and discovery of what Muslims did not know and that is that among them lived hidden hypocrites, indicating that there are those who are not sincere believers. This event disintegrated Muslim society into two categories: sincere believers, the faithful, who kept the truth and those who are not, but they pretended that they are believers and used their hidden nifaq and hypocrisy for attacks on islam and the believers.

KEYWORDS: False charges, false accusations, hadis al-ifk, hypocrisy, hypocrites, hypocrites, Revelation, Allah's Messenger, Aisha, r.a., Abu Bakr As-Siddiq's family, believers, The truthful daughter (As-Siddiqatu bintu AsSiddiq) 


\section{الأستاذ الدكتور محرم شتولانوفيتش}

الافتراء أو القذف العلني في الإسلام: الأمر التافه غير الضيار أو الإثم الكبير

\section{الخلاصة}

إن الله تعالى كان يرسل الرسل إلى الأرض ويربيهم وبربي أتباعهم من خلال

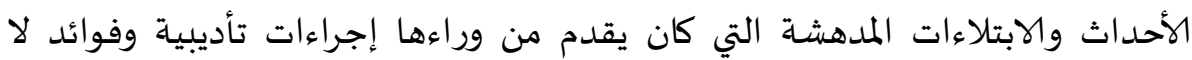

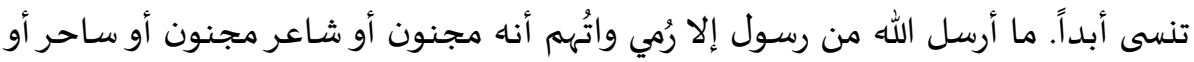

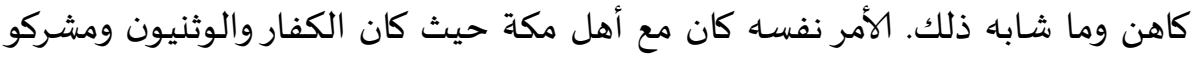

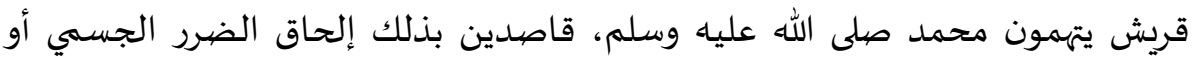

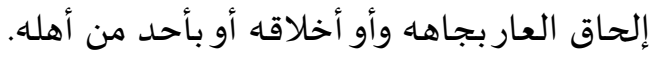

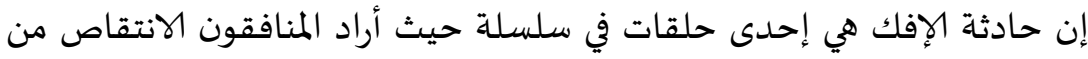

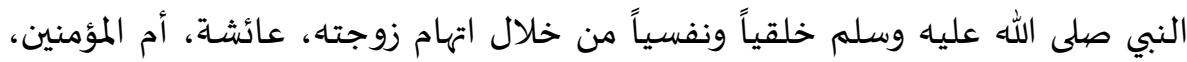

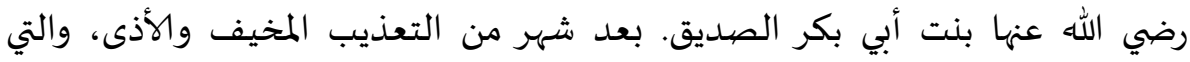

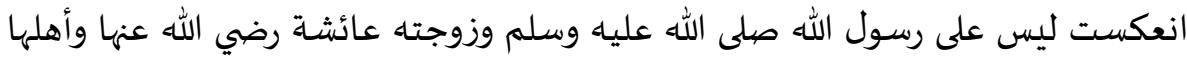

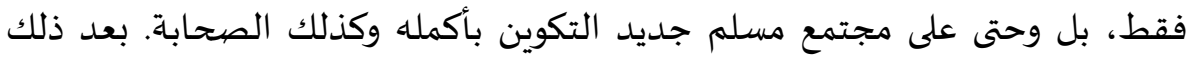

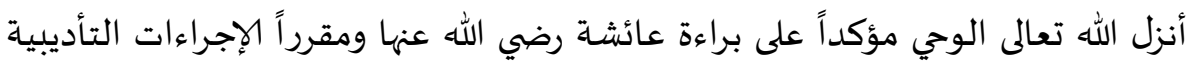

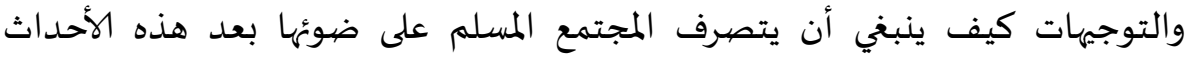

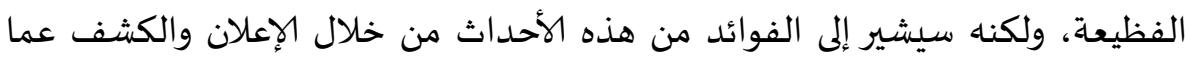

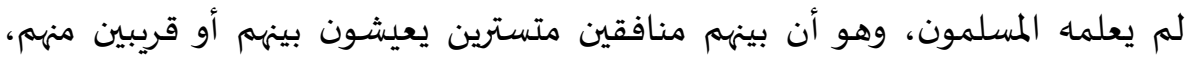
وهذا يعني أن هناك من ليس مؤمناً صادقاً.

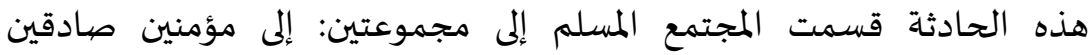

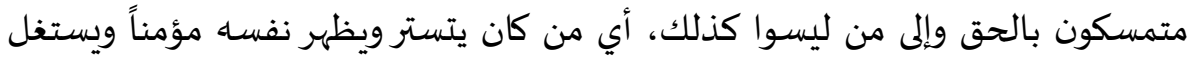
نفاقه المخفي للهجوم على الدين والمؤمنين.

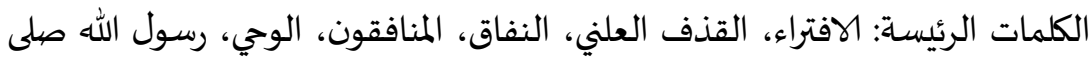

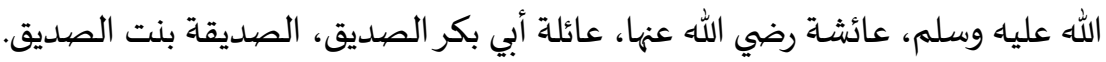

